\title{
Corporate Governance Mechanisms and Intellectual Capital Efficiency: Evidence from Malaysia
}

\author{
Hasmanezan Hassan ${ }^{1} \&$ Najihah Marha Yaacob ${ }^{1}$ \\ ${ }^{1}$ Faculty of Accountancy, University Teknologi MARA (Terengganu), Dungun, Terengganu, Malaysia \\ Correspondence: Hasmanezan Hassan, Faculty of Accountancy, University Teknologi MARA (Terengganu), \\ Dungun, 23000 Terengganu, Malaysia. E-mail: has.hassan83@yahoo.com
}

Received: March 19, 2017

Accepted: April 9, 2018

Online Published: December 15, 2018

doi:10.5539/ijef.v11n1p83

URL: https://doi.org/10.5539/ijef.v11n1p83

\begin{abstract}
The objective of this study is to investigate the relationship between Corporate Governance (CG) mechanisms and Intellectual Capital (IC) efficiency following the revision of the Malaysian Code of Corporate Governance (MCCG) in 2012. A final sample of 150 large companies was chosen from the companies listed on the main board of Bursa Malaysia for 2014. The Value Added Intellectual Coefficient (VAICTM) model was utilized to measure the IC efficiency and tested using multiple regression analysis. The multiple regression analysis revealed that board size and frequency of audit committee meetings have a significant and positive association with IC efficiency, but no evidence existed for an association between board composition and role duality on IC efficiency.The result of this study could be useful for regulators and policy makers, particularly to the Securities Commission Malaysia, to further revise and strengthen its MCCG. This study adds to the shortage of literature by providing evidence on the effects of CG attributes on IC efficiency subsequent to the revised Malaysian Code on Corporate Governance (MCCG) 2012.
\end{abstract}

Keywords: intellectual capital, VAIC ${ }^{\mathrm{TM}}$, agency theory, corporate governance mechanisms, Malaysia

\section{Introduction}

Driven by the emergence of the new economy, an awareness of intangible assets has become a necessity in order to enhance competitive advantage. Intangible assets create future wealth that is probably at risk of theft and damage.

The idea and philosophical theory of intangible assets have developed simultaneously (Pike, Fernström, \& Roos, 2005). A concise timeline of intangible capital development by Petty and Guthrie (2000) showed that the early 1980's was the era of the emergence of intangible value, which was conventionallyknown as goodwill. In early 1990 's, several common issues began to rise in the media regarding IC, and IC reporting by companies became a trend (Bontis, 1999). In 1994, Skandia, a Swedish financial firm, became one of the first companies to report intangible capital (IC), compiling information on IC collectively in a financial report to shareholders (Bontis, 2001). They believed in becoming a sustainable and established company by nurturing their roots. Leif Edvinsson, the chief architect behind Skandia's initiatives in IC, believed that an initial investment in IC would provide gains for the company over the long term (Edvinsson, 1997). Due to the significance of OECD's (2011) claims in 1970 and 2004 that IC had become a strategic factor for value creation in developed countries like the United Kingdom, the OCED conceptual models of investment needed to account for increasing investments in intangible capital.

There are varied insights for understanding the concept. Skandia AFS claimed that IC was the combination of human capital and structural capital (Edvinsson, 1997); it was also called a hidden or invisible asset that was constantly problematic to quantify (Brennan, 2001; Whiting \& Miller, 2008; Muhammad \& Ismail, 2009; Boda \& Szlávik, 2007; Dzinkowski, 2000), and some tended to name it as unaccounted capital (Abeysekera, 2006).

According to Edvinsson (1997), the IC components emphasizing technology innovation were followed by research and development with a consideration that employee productivity might lead to a long-term investment geared to a company's success. Goh (2005) also found a relationship between IC and efficiency in the commercial banking sector in Malaysia.However, researchers have indicated that IC has a positive and significant influence on a firm's performance and market value regardless of industry in disparate countries such 
as Malaysia (Abdullah \& Sofian, 2012), Thailand (Phusavat, Comepa, Sitko-Lutek, \& Ooi, 2011), Taiwan (Chen, Cheng, \& Hwang, 2005), and Italy (Pucci, Simoni, \& Zanni, 2013).

Due to the world economic crisis in 2008 and collapse of US companies in 2001, investors have demanded high-quality information. The need for voluntary IC disclosure was seen as enhancing transparency. However, managing IC is quite challenging. The adoption of better corporate governance (CG) systems would ensure the maximization of shareholder wealth through the efficient use of IC. Developmental studies on the relationship between IC and CG in terms of corporate culture and a firm's performance (Haniffa \& Cooke, 2002; Cerbioni \& Parbonetti, 2007; Tsai, Yu, \& Wen, 2013) have contributed the understanding on the influence of CG and IC on efficiency (Appuhami \& Bhuyan, 2015). CG may resolve the issues of information asymmetry, conflict of interest, and agency costs and lead to parity between the shareholders and the management to enhance a firm's transparency (Hidalgo, Garcia-Meca, \& Martinez, 2011).

Very little literature has explored issues concerning the influence of CG mechanisms for IC. In Malaysia, a few studies have examined the effects of CG on IC disclosures (Abdullah \& Sofian, 2012; Taliyang \& Jusop, 2011; Ahmed Haji \& Mohd Ghazali, 2013) prior to the revised Malaysian Code on Corporate Governance (MCCG) of 2012. This current study is expected to add to the literature that has examined the influential factors for determining IC efficiency after the revised MCCG of 2012. Thus, the purpose of this study is to investigate the effect of the composition of the board, board size, role duality and frequency of audit committee meetings on IC efficiency.

\section{Review of the Literature}

\subsection{Intellectual Capital}

IC comprises three main elements including: 1) human capital, 2) structural capital, and 3) relational capital (Bontis, 1999). Human capital is value added by the employees of an organization, including knowledge, talents, ingenuity, commitment, and intelligence (Bontis, 1999) that can be organized through guidance and learning (Keenan \& Aggestam, 2001). Structural capital comprises organizational innovation, efficient procedure, and quality of guidelines that include software systems, organizational structure, patents, copyright and trademarks (Guthrie \& Petty, 2000). Relational capital includes knowledge of surrounding connections external to the firm such as market channels, customers, suppliers, government and networks (Bontis, 1999). A stronger mixture of the IC elements leads to better generation of value. Several studies have stressed the significance of managing IC by reducing agency problems in organizations through emphasizing corporate governance systems (Hidalgo, Garcia-Meca, \& Martinez, 2011; Cerbioni \& Parbonetti, 2007; Li, Pike, \& Haniffa, 2008).

Consistent with the broad definition of IC that Itami and Roehl (1987) to Edvinsson (1997), and Pulic (2008) provided, IC includes specified technology network, an emphasis on customer satisfaction, a clear image and brand name of a company, and also valuable personnel that can add value to the company. The general meaning of IC can be specific to a categorical term, as discussed from Sveiby (1997), to Norton (1996), toEdvinsson and Malone (1997) and many more. Thereby, each meaning is based on a different perspective, contributes to a different framework and finally leads to organizing the formula for measurement respectively. Almost 42 methods for measuring IC (see Sveiby Knowledge Associates for example) exist, and IC has become an important research field that researchers are exploring (Goh, 2005). For instance, Sveiby(1997) formulated a framework named "The Intangible Asset Monitor" to measure intangible assets. He segregated intangible assets into three structures: 1) internal structure (employee and administrative systems), 2) external structure (customers, suppliers, and stakeholders), and 3) an individual's competence (skill, education, and experience). According to Goh (2005), the majority of studies focus on measuring intellectual capital models including: 1) Market Book Value Ratio (M/B), 2) Value Added Intellectual Capital Coefficient (VAICTM) by Pulic (1998) and 3) Tobin's Q.

The VAIC'M model that Pulic (1998) developed is a useful tool in helping management, shareholders and other stakeholders evaluate the value measurement of IC as an indicator to monitor and evaluate the performance of a firm's resources with respect to IC (Firer \& Williams, 2003; Phusavat, Compea, Sitko-Lutek, \& Ooi, 2011). Instead of just measuring a firm's IC, the VAICTM model also recognises the measurement of the efficiency of human capital, capital employed and structural capital. As Pulic (2008) said, VAIC ${ }^{\text {TM }}$ indicates how “... much new value has been created per invested monetary unit in each resource. The higher this coefficient the better the company's intellectual capital, which creates value more and more efficiently" (p. 20).

An overview of the VAIC model provides further insights on the concept and the process of the VAIC ${ }^{\text {TM model. }}$ Firer and Williams (2003) recognized several benefits of using the VAICTM model that included regulation and constant measurement of conduct. These benefits are well recognized and generally accepted in studies in several 
countries such as Malaysia (Goh, 2005; Muhammad \& Ismail, 2009), Iran (Mehralian, Rajabzadeh, Sadeh, \& Rasekh, 2012), Australia (Appuhami \& Bhuyan, 2015; Laing, Dunn, \& Hughes-Lucas 2010), Thailand (Phusavat, Comepa, Sitko - Lutek, \& Ooi, 2011) and many more. Nonetheless, the VAIC ${ }^{\text {TM }}$ model may lead to problems in computation, as for example, in companies that show a negative operating profit. This will describe that their input is more than their output; hence, this situation will reflect their productivity is low (Mehralian, Rajabzadeh, Sadeh, \& Rasekh, 2012).

\subsection{Underlying Theory}

Agency theory (AT) is commonly a major part topic in corporate governance. Additional perspectives on the concept of separation and ownership of control exist. For example, Fama and Jensen (1983) argued that "an effective system for decision control implies, almost by definition, that the control (ratification and monitoring) of decisions is to some extent separate from the management (initiation and implementation) of decisions" (p. 304). According to Adams (2007), due to the separation of ownership and control, the agent (manager) has been assigned the duty of conducting the business of a company on behalf of the principal.

Li, Pike, and Haniffa (2008) supported the viewpoint that IC disclosure could reduce the principal-agent problem indirectly in their examination of CG mechanisms including the composition of the board, board size, role duality and frequency of audit committee meetings among $100 \mathrm{UK}$ listed firms.

\subsection{Corporate Governance in Malaysia}

The MCCG was first introduced in March 2000 as an indicator of high quality CG in Malaysia. The MCCG was revised in 2007, 2011, and 2012, with the objective of improving corporate governance. The MCCG 2012 comprises 8 key principles and 26 recommendations. Generally, the rules emphasize guidelines for a board and its committees to uphold their duties successfully, ensure timely and the best possible disclosure of information, and promote transparency and accountability in financial reporting for Bursa Malaysia listed companies.

The first principle emphasizes establishing clear roles and responsibilities for the management and board, along with ethical standards. The second principle encourages strengthening the composition of the board by appointing a nominating committee as an advisor to recommend qualified candidates for membership. The third principle is reinforcing the independence of directors by emphasizing background criteria and ensuring that members are free from any conflicts of interest. The majority must be independent, and the chairman and the CEO positions must be held by different individuals. The fourth principle is to foster commitment. The board should ensure that its members schedule adequate time to carry out duties and responsibilities. The fifth principle is to uphold integrity in financial reporting by ensuring that applicable reporting is implemented and the relationship of auditors and management through the Audit Committee. The sixth principle is to recognize and manage risks by establishing an internal audit function. The seventh principle is to ensure timely and high-quality disclosure and to comply with Bursa Malaysia's disclosure requirements. Last is strengthening the relationship between the company and its shareholders by encouraging shareholders to attend general meetings and to encourage poll voting (MCCG, 2012).

\subsection{Conceptual Framework and Hypothesis Development}

The dependent variable is IC efficiency that uses the VAICTM model as a performance measurement. Meanwhile, independent variables comprise CG mechanisms. The CG variables, include board composition, board size, role duality and frequency of audit committee meetings. The control variables include Return on Equity (ROE) and audit committee size. Figure 1 illustrates the conceptual framework.

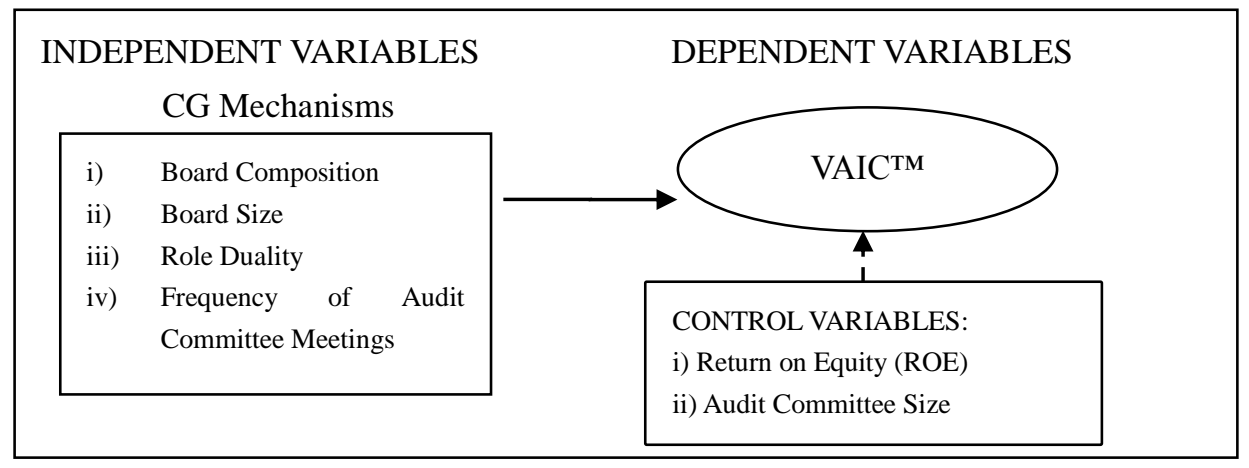

Figure 1. Conceptual framework 


\subsubsection{Board Composition}

Board composition refers to the use of independent outside directors in the organization. According to MCCG 2012, Recommendation 2.1, in order to strengthen the composition of the board directors, a nominating committee should be created, which should be comprised entirely of non-executive directors, the majority of whom should be independent directors. The chairman of the committee should be the senior independent director.

In accordance with AT, the purpose of having an outside non-executive director who is responsible for overseeing the management affairs is as a middle person to protect the interests of shareholders and to mitigate the powers of internal directors.

However, surprisingly, contrary to what might be expected to find relative to outside directors and firm performance, Barnhart and Rosenstein (1998) found a weak negative association between the proportion of outside directors and firm performance in the United States. The result suggests that the power of managers was more than that of outside directors, and managers were capable of overriding any decisions of the board. Kiel and Nicholson (2003) also found a negative relationship between independent directors and firm performance in Australia. Board composition is also impacted by various factors such as company age. Challenging Agency Theory, Kroll, Walters, and Le (2007) argued that boards of young firms having recently going public are best composed of a majority of original top management team members, rather than independent directors. That is because such board members possess valuable knowledge and understand the entrepreneurial visions of these firms and are in the best position to provide oversight. They also believed that outside directors might be used to execute their strategies rather than to monitor those managers.

Taliyang and Jusop (2011) believe that the presence of more independent directors would encourage the disclosure of more information. A majority of available independent directors on the board might be able to reduce the chances of conflicts of interest by top management and ensure that a strategy to enhance intellectual capital efficiently is conducted in an effective manner (Appuhami \& Bhuyan, 2015). Other studies such as that of $\mathrm{Li}$, Pike, and Haniffa (2008) also indicate that board composition as a corporate governance mechanism is a possible influence intellectual capital efficiency. Thus, this study posits that;

H1: There is a positive relationship between independent board composition and intellectual capital efficiency.

\subsubsection{Board Size}

Board size refers to the total number of members on a board of directors of an organization. Smaller board size can improve a firm's performance. According to Jensen (1993), large board size can produce miscommunication and an inability to control management conflicts due to the agency problem. The problem is seen as becoming worse when the board becomes too big and creates a dysfunctional environment (Lipton \& Lorsch, 1992). According to Appuhami and Bhuyan (2015) based on AT, a larger board may create problems of inefficiency in controlling manager's attitudes and will indirectly cause unproductive IC efficiency and, hence, be reflected in reduced company performance.

Previous studies have produced a variety of related results related to board size and firm performance, but the results have been mixed. Cerbioni and Parbonetti (2007) found a negative relationship between board size and intellectual capital disclosure but a positive association for external capital and human capital for European biotechnical companies. Hidalgo, Garcia-Meca, and Martinez (2011) found that an increase in the number of board members up to 15 had a beneficial effect on the disclosure of intangibles but an increase above this number had an adverse effect. Abeysekera's (2010) study in Nigeria examined the influence of board size on firms and found that firms disclosing more tactical internal capital and strategic human capital had a larger board size. Jackling and Johl (2009), who examined top Indian companies, found that a larger board size had a positive impact on firm performance. However, some studies have found a contrary result. Yermack (1996) using Tobin's $\mathrm{Q}$ as a measure of valuation studied 452 large industrial companies in the United States and found an inverse relationship between board size and value.

Some studies have found no specific limits for board size. In fact, Appuhami and Bhuyan (2015) studied Australian firms and found that that CEO duality, board composition and remuneration committee composition were significantly associated with IC. However, no evidence was found that board size effected IC. In Malaysia, the MCCG 2012 set no specific limit for the total number of members of a board, provided the board is beneficial in making decisions and discharges its fiduciary duties (MCCG, 2012). The code noted that a "no one size fits all approach" philosophy exists for corporate governance (p. 5). Thus, in line with Agency Theory, the present study hypothesizes that: 


\section{H2: There is a negative association between board size and intellectual capital efficiency.}

\subsubsection{Role Duality}

Role duality means the leadership functions as a chairman and chief executive officer (CEO) are served by the same persons in an organization. In Malaysia, the key principles of MCCG 2012, reinforce independence via Recommendation 3.4 which say that the position of chairman of the board and CEO should be held by different individuals, and the chairman must be a non-executive member of the Board.

Several studies have found that CEO duality reduced the amount of information disclosed. Gul and Leung (2004) investigated all active biotech firms listed on the US Stock exchange from 1 January 2005 to 31 December 2010. They found that CEO duality negatively impacted the amount of information disclosed, and, in all their models, they found that when the CEO is also Chairman of the Board, firms tended to disclose less (Gul \& Leung, 2004). Similar situations were found in France (Lakhal, 2005), Hong Kong (Ho \& Wong, 2001), the United States (Abbott, Park, \& Parker, 2000) and the United Kingdom (Forker, 1992). These studies all found that CEO duality leads to situations in which sufficient and related information tend not to be disclosed. Additionally, if the roles of CEO and chairman are not separated, the independence of the board may be compromised (Bliss, 2011), and multiple roles may also give rise to conflicts of interest that indirectly impair shareholder value (Dalton \& Kesner, 1987).

Nonetheless, prior studies have exhibited mixed results on role duality. Al-Shammari and Al-Sultan (2010) found no association between role duality and voluntary disclosure. Al-Shammari and Al-Sultan's (2010) study, which was conducted in Kuwait, clarified the reasons for no relationship between CEO duality and voluntary disclosure, saying that the presence of a voluntary audit committee was associated with an increase in voluntary disclosure. Both Weir, Laing, and McKnight (2002) and Vafeas and Theodorou (1998) also found no evident relationship regarding role duality and firm performance in the United Kingdom. Appuhami and Bhuyan (2015) showed that role duality was associated with IC efficiency in Australia. Donaldson and Davis (1991) found that a shared role provided some support for stewardship theory but found no relationship with Agency Theory in the United States. Cerbioni and Parbonetti's (2007 empirical results showed that role duality was strongly and negatively associated with external capital but had no effect on internal capital and human capital among European biotechnology firms. In support of Agency Theory, Bliss (2011) found that role duality negatively affected board functions and suggested CEO duality hindered board independence in Australia. Thus, in support of Agency Theory and based on previous study, the present study hypothesizes that:

\section{H3. There is negative association between role duality and intellectual capital efficiency.}

\subsubsection{Frequency of Audit Meeting}

The revised MCCG code 2012 requires that an audit committee meeting is held not less than four times a year. Some have found that audit committees that meet more frequently demonstrated better and more efficient monitoring performance over management (Karamanou \& Vafeas, 2005). Raghunandan and Rama (2007) found that the number of audit committee meetings was increased when there was a large audit committee size. Some empirical evidence has also shown a negative relationship between frequent audit committee meetings and earnings management (McMullen \& Raghunandan, 1996).

Li, Mangena, and Pike (2012) investigated the relationship between audit committee characteristics and IC disclosure. The study found a positive relationship between the frequency of audit committee meetings and IC disclosure. Yin, Gao, Li, and Lv's (2012) observational study found the frequency of audit committee meetings was negatively associated with the proportion of shares owned by a majority shareholder. Because of the potential impact of the number of audit committee meetings upon intellectual capital disclosure in Malaysia, the current study hypothesizes that:

H4: There is a positive relationship between frequency of audit committee meetings and intellectual capital efficiency.

\subsubsection{Control Variables}

The following control variables are used in this current study. This includes ROE, which is used to measure company performance. Previous studies such as those of Appuhami and Bhuyan (2015) and Keenan and Aggestam (2001) have found a significant and positive relationship between ROE and IC efficiency. The argument is that firms interested in investing and using IC efficiently consider that IC would enhance performance.

Another control variable used is audit committee size (ACSIZE), which measures the total number of audit 
committee members. The revised code of MCCG 2012 identifies tasks of the audit committee board as appointing an external auditor, discussing the nature of audit, an evaluation of internal control systems, reviewing the internal audit programme and ensuring that the financial statement complies with significant accounting policies and procedures. As such, Ho and Wong (2001) claimed that an audit committee could reduce the agency cost problem and indirectly could enhance disclosure requirement.

\section{Data \& Methodology}

\subsection{Sample Selection}

The data in this study comprises publicly available information mainly obtained from the annual reports of the companies listed on the main board of Bursa Malaysia in 2014. The use of corporate annual report is categorized as a secondary source of data and was used to ensure the accuracy and precision of the data better than through interviews or questionnaires Sekaran and Bougie (2009). Ahmed Haji and Mohd Ghazali (2013) and Appuhami and Bhuyan (2015) used larger companies because they believed that information to be more reliable information and also contained a larger amount of IC data (Guthrie \& Petty, 2000).

According to Sekaran and Bougie (2009), a sample size of 201 is recommended for a population of 800, which was the number of companies listed on Bursa Malaysia as of 31 December 2014. The initial sample of 200 was reduced to 150 firms due to the incomplete data and banking and financial institutions (including REITS, closed-end fund and exchange traded fund were excluded. The final sample was 150 companies representing seven industry sectors.

\subsection{Description and Measurement of Variables}

\subsubsection{Dependent Variable}

To compute the VAIC ${ }^{\text {TM }}$ model, three major indicators are recognized. First, the capital employed efficiency coefficient (CEE) is computed. The formula is as follows:

$$
C E E_{i}=V A_{i} / C A_{i}
$$

Where; $\mathrm{CEE}_{\mathrm{i}}$ is the capital employed efficiency coefficient for firm $\mathrm{i}$; whereas, $\mathrm{VA}_{\mathrm{i}}$ is value added for the firm $\mathrm{i}$; $\mathrm{CA}_{\mathrm{i}}$ is the book value of the net assets for firm $\mathrm{i}$.

$\mathrm{VA}_{\mathrm{i}}$ can be calculated as follows:

$$
V A_{i}=I_{i}+D P_{i}+D_{i}+T_{i}+M_{i}+R_{i}
$$

Where,

$\mathrm{I}_{\mathrm{i}}=$ interest;

$\mathrm{DP}_{\mathrm{i}}=$ depreciation;

$\mathrm{D}_{\mathrm{i}}=$ dividend;

$\mathrm{T}_{\mathrm{i}}=$ taxes;

$\mathrm{M}_{\mathrm{i}}$ = equity of minority shareholders in net income of subsidiaries of a firm; and

$\mathrm{R}_{\mathrm{i}}=$ retained earning.

The next step is to measure the efficiency of the human capital on the value creation of the firm (HCE). The formula is computed in terms of HCE:

$$
H C E_{i}=V A_{i} / H C_{i}
$$

Where; $\mathrm{HCE}_{\mathrm{i}}$ is the human capital efficiency coefficient for the firm $\mathrm{i}$; $\mathrm{VA}_{\mathrm{i}}$ is the value added for the firm $\mathrm{i}$ and $\mathrm{HC}_{\mathrm{i}}$ is the total salaries and wages for the firm $\mathrm{i}$.

Another component of IC is structural capital efficiency coefficient (SC) is computed as follows:

$$
S C E_{i}=S C_{i} / V A_{i}
$$

Where; $\mathrm{SCE}_{\mathrm{i}}$ is structural capital efficiency for the company $\mathrm{i}$; $\mathrm{SC}_{\mathrm{i}}$ is the structural capital for the firm $\mathrm{i}$; and $\mathrm{VA}_{\mathrm{i}}$ is value added for the firm $\mathrm{i} . \mathrm{SC}_{\mathrm{i}}$ is computed as;

$$
S C_{i}=V A_{i}-H C_{i}
$$

Where; $\mathrm{SC}_{\mathrm{i}}$ is the structural capital for the firm $\mathrm{i}$; $\mathrm{VA}_{\mathrm{i}}$, is the value added for the firm $\mathrm{i}$; and $\mathrm{HC}_{\mathrm{i}}$ represents total salary and wage costs for the firm i.

Intellectual capital efficiency (ICE) is the sum of the two coefficients of human and structural capitals: 


$$
I C E=H C E+S C E
$$

Where; ICE is the intellectual capital efficiency coefficient, HCE is the human capital efficiency coefficient; SCE is the structural capital efficiency coefficient.

Hence, overall value added intellectual coefficient VAIC ${ }^{\text {тM }}$ is total sum of all value creation efficiency indicators:

$$
V A I C_{i}=+H C E_{i}+S C E_{i}+C E E_{i}
$$

Where; $\mathrm{VAIC}_{\mathrm{i}}$ is the value added intellectual capital efficiency coefficient, $\mathrm{HCE}_{\mathrm{i}}$ is the human capital efficiency coefficient; $\mathrm{SCE}_{\mathrm{i}}$ is the structural capital efficiency coefficient and $\mathrm{CEE}_{\mathrm{i}}$ is the capital employed efficiency coefficient.

Initially, before these three major indicators are measured, the Value Added $\left(\mathrm{VA}_{\mathrm{it}}\right)$ of all resources is detected. This study uses the latest and current methodology approach as proposed by Appuhami and Bhuyan (2015) and recommended by Mehralian, Rajabzadeh, Sadeh, and Rasekh (2012).

\subsubsection{Independent Variables}

Board composition (BCOM) is measured by the proportion of independent directors on the board of directors. Much literature has used the same measurement, for instance, Appuhami and Bhuyan (2015), Taliyang and Jusop (2011), and Li, Pike, and Haniffa (2008). Board size (BSIZE) is measured by the total number of members on the board of directors. The studies that have used a similar measurement include those of Cerbioni and Parbonetti (2007); Ahmed Haji and MohdGhazali (2013); and Hidalgo, Garcia-Meca, and Martinez (2011). Role duality (RDUAL) is measured by a dummy variable with the value of " 1 " if there is a role duality and " 0 " if otherwise. Previous studies that used similar measurement include those of Bliss (2011) and Gul and Leung (2004). Frequency of audit committee meetings (MAC) is measured by frequency of audit committee meetings held during the financial year. Li, Mangena, and Pike (2012) and Taliyang and Jusop (2011) also used the frequency of audit committee meetings held. Table 1 presents a summary of the measurements for all variables.

Table 1. Measurement of variables

\begin{tabular}{llll}
\hline Type & Variable & Definition & Measurement \\
\hline Dependent variable & VAIC & Intellectual Capital & VAIC'T \\
Independent variable & BCOM & Board Composition & Proportion of independent directors on board of directors. \\
& BSIZE & Board size & Total number of member's board of directors. \\
& RDUAL & Role of duality & Dummy variable of '1' if there is role duality and '0' otherwise. \\
& MAC & Frequency of Audit & Frequency of audit committee meeting held during the year. \\
& & Committee Meeting & \\
Control variable & ROE & Firm performance & Net profit divided by equity capital \\
& ACSIZE & Audit Committee Size & Total members in Audit Committee \\
\hline
\end{tabular}

\subsection{The Empirical Model}

The empirical model that is used in this study comprises:

$$
V A I C^{\mathrm{TM}}=1 \beta B C O M P+2 \beta B S I Z E+3 \beta R D U A L+4 \beta M A C+5 \beta R O E+6 \beta A C S I Z E+e
$$

Where $\beta$ and e represent the parameters and error term respectively:

VAIC $=$ Value added Intellectual Coefficient;

$\mathrm{BCOMP}=$ Proportion of independent directors on board of directors;

BSIZE $=$ Proportion of number of members sitting on the board of directors;

RDUAL = Proportion of CEO duality;

MAC $=$ Proportion of frequency of audit committee meeting held;

$\mathrm{ROE}=$ Firm performance; and

ACSIZE $=$ Audit committee size .

\section{Results}

\subsection{Descriptive Analysis}

Table 2 presents the descriptive statistics for all regression variables. The mean for IC efficiency was 11.1108 , 
which indicates that a new value (RM11.11) has been created per invested monetary unit (RM1) in each resource for the year 2014.

The statistics on the board composition indicates that a mean of $61.24 \%$ of board company directorships was held by independent non-executive directors in the tested samples. The mean for board size of the present study shows that the average constituted approximately 8 members (mean $=8.24$ ) with a range of 14 to 4 .

The measurement of company CEO duality used a dummy variable of " 1 " for the role of duality which indicates a combination of tasks and " 0 " for otherwise. The range was between 0 and $100 \%$. The mean for role duality was only $12 \%$ as compared to the separate role tasks of CEO and Chairman of $88 \%$. For the frequency of audit committee meeting, the mean of 7.59 indicated that on average about 8 audit committee meetings were held during the financial year. In terms of control variables, the mean for Return on Equity (ROE) was 14.65\%, and audit committee size of was almost $4($ mean $=3.67)$ members on a board.

Table 2. Descriptive statistics

\begin{tabular}{lccccc}
\hline \multicolumn{1}{c}{ Variable } & $\mathbf{N}$ & Mean & Std. Deviation & Minimum & Maximum \\
\hline VAICTM & 150 & 11.1108 & 8.93766 & 1.75 & 50.85 \\
BCOMP & 150 & 0.6124 & 0.38024 & 0.20 & 1.90 \\
BSIZE & 150 & 8.24 & 2.216 & 4 & 14 \\
RDUAL & 150 & 0.12 & 0.326 & 0 & 1 \\
MAC & 150 & 7.59 & 4.474 & 0.00 & 18 \\
ROE & 150 & 0.1465 & 0.18513 & 3 & 1.72 \\
ACSIZE & 150 & 3.67 & 0.939 & & 8 \\
\hline
\end{tabular}

\subsection{Multiple Regression Analysis}

\subsubsection{Diagnostic Test Results}

Several diagnostics tests were conducted to determine the validity of data for multiple regression analysis. As presented in Table 3, the results of variance inflation factor (VIF) were less than 10 for all variables, which signifies that a multicollinearity problem did not exist. Then, tests on the assumptions of linearity, normality, and homoscedasticity revealed that the histogram had a bell shape, the graph of normal P-P plot was scattered on a straight line, and all the residuals seemed to be randomly dispersed around the horizontal line (scatter plot).Hence, a visual inspection of the data discovered no serious violation of the assumptions of multiple regression, so the use of multiple regression analysis was appropriate.

\subsubsection{Multiple Regression Results}

Table 3 presents the regression results for all variables. The multiple regression result shows a value for the $\mathrm{F}$ ratio of 38.425 and $(p=0.000)$, indicating that the model is highly significant. The Adjusted $R^{2}$ of 0.601 , implies that $60.1 \%$ of the variation in the dependent variables was explained in the regression model, while the remaining $39.9 \%$ was due to other factors.

The regression results discovered that two (2) out of four (4) hypotheses variables significantly influence IC efficiency in the predicted direction.For board composition (BCOMP) this study found that IC efficiency was negatively related to the proportion of independent directors. Thus, hypothesis 1 is not supported.For board size (BSIZE), the result revealed that, at the 5\% significant level, the p-value (0.019) was smaller than $\alpha=0.01$. Thus, hypothesis 2 was supported, which indicates that the larger board size, the lower the number of firms that use IC efficiently. For role duality (RDUAL), because the calculated p-value (0.843) was higher than $\alpha=0.10$, hypothesis 3 was not supported. For frequency of audit committee meeting (MAC, the study revealed that the p-value was 0.000 and highly significant at the $1 \%$ level. Thus, hypothesis 4 was supported and the conclusion can be made that the frequent of audit committee meetings had a significant effect IC efficiency.

In terms of control variables, Return on Equity (ROE) was insignificantly related to IC efficiency, while audit committee size (ACSIZE) had a significant influence ( $\mathrm{p}$-value $=0.022$ ) on IC efficiency at the 5\% significance level. 
Table 3. Multiple regression results

\begin{tabular}{|c|c|c|c|c|c|}
\hline Variable & B & t-value & Sig. & Tolerance & VIF \\
\hline (Constant) & 11.590 & 4.806 & 0.000 & & \\
\hline BCOMP & -4.335 & -3.430 & 0.001 & 0.926 & 1.080 \\
\hline BSIZE & -0.516 & -2.365 & 0.019 & 0.916 & 1.092 \\
\hline RDUAL & -0.306 & -0.210 & 0.834 & 0.947 & 1.056 \\
\hline MAC & 1.461 & 13.381 & 0.000 & 0.896 & 1.116 \\
\hline ROE & -0.952 & -0.375 & 0.708 & 0.969 & 1.032 \\
\hline ACSIZE & -1.222 & -2.309 & 0.022 & 0.866 & 1.155 \\
\hline \multicolumn{6}{|l|}{ Model Summary } \\
\hline $\mathrm{R}$ & & & & & 0.786 \\
\hline $\mathrm{R}^{2}$ & & & & & 0.617 \\
\hline Adjusted $\mathrm{R}^{2}$ & & & & & 0.601 \\
\hline F Value & & & & & 38.425 \\
\hline Significance & & & & & 0.000 \\
\hline
\end{tabular}

\section{Discussion and Conclusion}

The objective of this paper was to investigate the relationship between CG mechanisms subsequent to the revised code of MCCG 2012 and IC efficiency. The CG structure included board composition, board size, role duality, and frequency of audit committee meetings. A final sample of 150 companies was chosen from the companies listed on the main board of Bursa Malaysia for the year 2014.

The study discovered that two (2) of CG characteristics, namely, board size and frequency of audit committee meetings, were significant factors that influenced IC efficiency whereas board composition and CEO role duality had no significant influence on IC efficiency. The regression results revealed that the proportion of independent directors was negatively related to the IC efficiency, which contradicts the expected hypothesis and does not support the underlying Agency Theory. The insignificant result of the hypothesis might be due to several reasons. According to Barnhart and Rosenstein (1998) top managerial ownership is more powerful than outside directors because they are able to override some decisions. Moreover, superior corporate performance will be linked to a majority of inside directors as they strive to maximise profits by having a better understanding of the company and they are capable of making superior decisions. The result of this study is in line with the previous literature on the Malaysian environment (See Abdul Rashid et al., 2012).

Board size had a significant negative association with IC efficiency. Even though MCCG 2012 did not recommend any precise number for board size, an ideal number must be suitable and relevant to a company in the Malaysian context. A larger board size may result in disagreements and thwart achieving consensus on some issues. According to Appuhami and Bhuyan (2015), a larger board may create problems of inefficiency in controlling the attitudes of managers, thus it will result in lower IC efficiency. The finding of this current study is consistent with that of Yermack (1996) who discovered that a small number of directors provides benefits in terms of CEO performance incentives, financial ratios, and growth opportunities.

In the context of CEO duality, this study discovered no significant association between duality role and IC efficiency. The insignificant result contradicted the requirements of revised code of MCCG 2012 designed to reinforce the separation of the positions of the Chairman Board and CEO. In this study, the insignificant result may be possibly due to the small proportion and low frequency of CEO duality (12\% of role duality).

The frequency of audit committee meetings had a significant positive relationship with IC efficiency. The result is consistent with the studies conducted by Li, Mangena, and Pike (2012) and Li, Pike, and Haniffa (2008) that revealed a significant positive relationship between the level of intellectual capital disclosure and the frequency of audit committee meetings. The result suggests that audit committee meetings are a way to control the attitudes of board and to mitigate information asymmetry through IC disclosure.

The result of this study could be useful to regulators and policy makers, particularly to the Securities Commission Malaysia to further revise and strengthen its MCCG. Future research might investigate other CG mechanisms that might influence IC efficiency. In addition, longitudinal study could be conducted and more powerful data analysis such as using panel data analysis could be used in order to provide richer interpretation and a powerful understanding (Yaacob \& Che-Ahmad, 2012) of the effects of CG characteristics on IC efficiency. 


\section{References}

Abbott, L. J., Park, Y., \& Parker, S. (2000). The effect of audit committee activity and independence on corporate fraud. Managerial Finance, 55-67. https://doi.org/10.1108/03074350010766990

Abdul Rashid, A., Ibrahim, M. K., Othman, R., \& See, K. F. (2012). IC disclosures in IPO prospectuses: Evidence from Malaysia. Journal of Intellectual Capital, 13(1), 57-80. https://doi.org/10.1108/14691931211196213

Abdullah, D. F., \& Sofian, S. (2012). The Relationship between Intellectual Capital and Corporate Performance. The 2012 International Conference on Asia Pacific Business Innovation \& Technology Management (pp. 537-541). https://doi.org/10.1016/j.sbspro.2012.03.227

Abeysekera, I. (2006). The project of intellectual capital disclosure: Researching the research. Journal of Intellectual Capital, 7(1), 61-77. https://doi.org/10.1108/14691930610639778

Abeysekera, I. (2010). The influence of board size on intellectual capital disclosure by Kenyan listed firms. Journal of Intellectual Capital, 11(4), 504-518. https://doi.org/10.1108/14691931011085650

Adams, S. (2007). Fundamentals of Business Economics. Retrieved from http://www.cimaglobal.com/documents/importeddocuments/fm_feb08_p46-48.pdf

Ahmed, H. A., \& Mohd, G. N. A. (2013). A Longitudinal Examination of Intellectual Capital Disclosures and Corporate Governance Attributes in Malaysia. Asian Review of Accounting, 27-52. https://doi.org/10.1108/13217341311316931

Al-Shammari, B., \& Al-Sultan, W. (2010). Corporate governance and voluntary disclosure in Kuwait. International Journal of Disclosure and Governance, 262-280. https://doi.org/10.1057/jdg.2010.3

Appuhami, R., \& Bhuyan, M. (2015). Examining the influence of corporate governance on intellectual capital efficiency: Evidence from top service firms in Australia. Managerial Auditing Journal, 347-372. https://doi.org/10.1108/MAJ-04-2014-1022

Azman, H., \& Kamaluddin, A. (2012). Corporate governance mechanisms and intellectual capital disclosure in Malaysian GLCs. 3rd International Conference on Business and Economic Reserach (3rd ICBER 2012) Proceeding (pp. 1-32). Bandung.

Barnhart, S. W., \& Rosenstein, S. W. (1998). Board composition, managerial ownership, and firm performance: An empirical analysis. Financial Review, 33(4), 1-16. https://doi.org/10.1111/j.1540-6288.1998.tb01393.x

Bliss, M. A. (2011). Does CEO duality constrain board independence? Some evidence from audit pricing. Accounting and Finance, 51(2), 361-380. https://doi.org/10.1111/j.1467-629X.2010.00360.x

Boda, G., \& Szlávik, P. (2007). Alternative Accounting to Manage Intellectual Capital. The Electronic Journal of Knowledge Management, 5(1), 7-18.

Bontis, N. (1999). Managing organizational knowledge by diagnosing intellectual capital: Framing and advancing the state of the field. International Journal TechnologyManagement, 18(5/6/7/8), 433-463.

Bontis, N. (2001). Assessing knowledge assets:A review of the models used to measure intellectual capital. International Journal of Management Review, 3(1), 41-60. https://doi.org/10.1111/1468-2370.00053

Brennan, N. (2001). Reporting intellectual capital in annual reports: Evidence from Ireland. Accounting, Auditing and Accountability Journal, 14(4), 423-436. https://doi.org/10.1108/09513570110403443

Cerbioni, F., \& Parbonetti, A. (2007). Exploring the Effects of Corporate Governance on Intellectual Capital. European Accounting Review, 16(4), 791-826. https://doi.org/10.1080/09638180701707011

Chen, M. C., Cheng, S. J., \& Hwang, Y. (2005). An empirical investigation of the relationship between intellectual capital and firms' market value and financial performance. Journal of Intellectual Capital, 6(2), 159-176. https://doi.org/10.1108/14691930510592771

Dalton, D. R., \& Kesner, I. F. (1987). Composition and CEO Duality in Board of Directors: An International perspectives. Journal of International 33-42. https://doi.org/10.1057/palgrave.jibs.8490410

Donaldson, L., \& Davis, J. H. (1991). Stewardship Theory or Agency Theory: CEO Governance and Shareholder Returns. Australian Journal of Management, 16(1), 49-65. https://doi.org/10.1177/031289629101600103 
Dzinkowski, R. (2000). The measurement and management of intellectual capital: An introduction. International Management Accounting, 78(2), 32-36.

Edvinsson, L. (1997). Developing Intellectual Capital at Skandia. Long Range Planning, 30(3), 366-373. https://doi.org/10.1016/S0024-6301(97)90248-X

Edvinsson, L., \& Malone, M. S. (1997). Intellectual Capital: Realizing Your Company's True Value by Finding Its Hidden Brainpower. New York, NY: HarperCollins.

Fama, E. F., \& Jensen, M. C. (1983). Separation of Ownership and Control. Journal of Law and Economics, 26(2), 301-325. https://doi.org/10.1086/467037

Firer, S., \& Williams, S. M. (2003). Intellectual capital and traditional measures of corporate performance. Journal of Intellectual Capital, 4(3), 348-360. https://doi.org/10.1108/14691930310487806

Forker, J. J. (1992). Corporate Governance and Disclosure Quality. Accounting and Business Research, 22(86), 111-124. https://doi.org/10.1080/00014788.1992.9729426

Fülöp, M. T. (2014). Why Do We Need Effective Corporate Governance? International Advances in Economic Research, 227-228. https://doi.org/10.1007/s11294-013-9430-3

Goh, P. C. (2005). Intellectual capital performance of commercial banks in Malaysia. Journal of Intellectual Capital, 6(3), 385-396. https://doi.org/10.1108/14691930510611120

Gul, F. A., \& Leung, S. (2004). Board leadership, outside directors expertise and voluntary corporate disclosures. Journal of Accounting and Public Policy, 23, 351-379. https://doi.org/10.1016/j.jaccpubpol.2004.07.001

Guthrie, J., \& Petty, R. (2000). Intellectual capital: Australian annual reporting practices. Journal of Intellectual Capital, 1(3), 241-251. https://doi.org/10.1108/14691930010350800

Haniffa, R., \& Cooke, T. (2002). Culture,Corporate Governance and Disclosure in Malaysian. Abacus, 38(3), 317-349. https://doi.org/10.1111/1467-6281.00112

Hidalgo, R. L., Garcia-Meca, E., \& Martinez, I. (2011). Corporate Governance and Intellectual Capital Disclosure. Journal of Business Ethics, 100(3), 483-495. https://doi.org/10.1007/s10551-010-0692-x

Ho, S. S., \& Wong, K. S. (2001). A Study of the Relationship Between Corporate Governance Structures and the Extent of Voluntary Disclosure. Journal of International Accounting, Auditing and Taxation, 10(2), 139-156. https://doi.org/10.1016/S1061-9518(01)00041-6

Itami, H., \& Roehl, T. (1987). Mobilizing Invisible Assets. London: Harvard University Press.

Jackling, B., \& Johl, S. (2009). Board structure and firm performance: Evidence from India's top companies. Corporate Governance: An International Review, 17(4), 492-509. https://doi.org/10.1111/j.1467-8683.2009.00760.x

Jensen, M. C. (1993). The Modern Industrial Revolution, Exit, and the Failure of Internal Control System. The Journal of Finance, 48(3), 831-880. https://doi.org/10.1111/j.1540-6261.1993.tb04022.x

Joshi, M., Cahill, D., Sidhu, J., \& Kansal, M. (2013). Intellectual capital and financial performance: An evaluation of the Australian financial sector. Journal of Intellectual Capital, 14(2), 264-285. https://doi.org/10.1108/14691931311323887

Kaplan, R. S., \& Norton, D. P. (1996). Linking the Balance Scorecard to the Strategy. Retrieved from http://www.strimgroup.com/sites/default/files/images/PDF/KaplanNorton_Linking-the-BSC-to-Strategy.pdf

Karamanou, I., \& Vafeas, N. (2005). The Association between Corporate Boards, Audit Committees, and Management Earnings Forecasts: An Empirical Analysis. Journal of Accounting Research, 43(3), 453-486. https://doi.org/10.1111/j.1475-679X.2005.00177.x

Keenan, J., \& Aggestam, M. (2001). Corporate governance and intellectual capital: Some conceptualisations. Corporate Governance: An International Review, 9(4), 259-275. https://doi.org/10.1111/1467-8683.00254

Kiel, G. C., \& Nicholson, G. J. (2003). Board composition and corporate performance: How the Australian experience informs contrasting theories of corporate governance. Corporate Governance: An International Review, 11(3), 189-205. https://doi.org/10.1111/1467-8683.00318

Komnenic, B., \& Pokraj, D. (2012). Intellectual capital and corporate performance of MNCs in Serbia. Jounal of Intellectual Capital, 13(1), 106-119. https://doi.org/10.1108/14691931211196231 
Kroll, M., Walters, B. A., \& Le, S. A. (2007). The impact of board composition and top management team ownership structure on post-IPO performance in young entrepreneurial firms. Academy of Management Journal, 50(5), 1198-1216.

Laing, G., Dunn, J., \& Hughes-Luca, S. (2010). Applying the VAIC model to Australian hotels. Journal of Intellectual Capital, 11(3), 269-283. https://doi.org/10.1108/14691931011064545

Lakhal, F. (2005). Voluntary Earnings Disclosures and Corporate Governance: Evidence from France. Review of Accounting and Finance, 4(3), 64-85. https://doi.org/10.1108/eb043431

Li, J., Mangena, M., \& Pike, R. (2012). The Effect of Audit Committee Characteristics on Intellectual Capital Disclosure. The British Accounting Review, 44, 98-110. https://doi.org/10.1016/j.bar.2012.03.003

Li, J., Pike, R., \& Haniffa, R. (2008). Intellectual capital disclosure and corporate governance structure in UK firms. Accounting and Business Research, 137-159. https://doi.org/10.1080/00014788.2008.9663326

Lipton, M., \& Lorsch, J. W. (1992). A modest proposal for improved corporate governance. Bussiness Lawyer, 48(1), 59-77.

McMullen, D. A., \& Raghunandan, K. (1996). Enhancing audit committee effectiveness. Journal of Accountancy, 182(2), 79-81.

Mehralian, G., Rajabzadeh, A., Reza Sadeh, M., \& Reza Sadeh, H. (2012). Intellectual Capital and Corporate Performance in Iranian Pharmaceutical Industry. Journal of Intellectual Capital, 13(1), 138-158. https://doi.org/10.1108/14691931211196259

Muhammad, N. M., \& Ismail, M. K. (2009). Intellectual Capital Efficiency and Firm's Performance: Study on Malaysian Financial Sectors. International Journal of Economics and Finance, 1(2), 206-212. https://doi.org/10.5539/ijef.v1n2p206

Organisation for Economic Cooperation and Development. (2011). Retrieved March 12, 2015 from http://www.oecd.org/sti/inno/46349020.pdf

Petty, R., \& Guthrie, J. (2000). Intellectual capital literature review Measurement, reporting and management. Journal of Intellectual Capital, 1(2), 155-176. https://doi.org/10.1108/14691930010348731

Phusavat, K., Comepa, N., Sitko-Lutek, A., \& Ooi, B. K. (2011). Interrelationships between intellectual capital and performance: Empirical examination. Industrial Management \& Data Systems, 111(6), 810-829. https://doi.org/10.1108/02635571111144928

Pike, S., Fernström, L., \& Roos, G. (2005). Intellectual capital: Management approach in ICS Ltd. Journal of Intellectual Capital, 6(4), 489-509. https://doi.org/10.1108/14691930510628780

Pucci, T., Simoni, C., \& Zanni, L. (2013). Measuring the relationship between marketing assets, intellectual capital and firm performance. Journal of Management and Governance, 19(3), 1-28. https://doi.org/10.1007/s10997-013-9278-1

Pulic, A. (1998). Measuring the performance of intellectual potential in knowledge economy. 2nd McMaster World Congress on Measuring and Managing Intellectual Capital. Hamilton.

Pulic, A. (2008). The Principles of Intellectual Capital Efficiency - A Brief Description. Retrieved from http://www.cik-hr.com/data/principles_2008.pdf

Raghunandan, K., \& Rama, D. V. (2007). Determinants of Audit Committee Diligence. Accounting Horizons, 21(3), 265-279. https://doi.org/10.2308/acch.2007.21.3.265

Sekaran, U., \& Bougie, R. (2009). Research Methods for Business A Skill Building Approach (5th ed.). United Kingdom: John Wiley \& Sons Ltd.

Sveiby, E. K. (1997). The Intangible Assets Monitor. Journal of Human Resource Costing \& Accounting, 2(1), 73-97. https://doi.org/10.1108/eb029036

Taliyang, S. M., \& Jusop, M. (2011). Intellectual Capital Disclosure and Corporate Governance Structure: Evidence in Malaysia. International Journal of Business and Management, 6(12), 109-117. https://doi.org/10.5539/ijbm.v6n12p109

Tsai, J. H., Yu, J., \& Wen, S. Y. (2013). Intellectual Capital, Corporate Governance and Firm Performance. Information Management and Business Review, 482-491. https://doi.org/10.5296/rae.v8i1.8675

Vafeas, N., \& Theodorou, E. (1998). The Relationship Between Board Structure and Firm Performance in the 
UK. The British Accounting Review, 30(4), 383-407. https://doi.org/10.1006/bare.1998.0075

Weir, C., Laing, D., \& McKnight, P. J. (2002). Internal and External Governance Mechanisms: Their Impact on the Performance of Large UK Public Companies. Journal of Business Finance \& Accounting, 29(5\&6). https://doi.org/10.1111/1468-5957.00444

Whiting, R. H., \& Miller, J. C. (2008). Voluntary disclosure of intellectual capital in New Zealand annual reports and the "hidden value". Journal of Human Resource Costing \& Accounting, 12(1), 26-50. https://doi.org/10.1108/14013380810872725

Williams, S. M. (2001). Is intellectual capital performance and disclosure practices related? Journal of Intellectual Capital, 2(3), 192-203. https://doi.org/10.1108/14691930110399932

Yaacob, N. M., \& Che-Ahmad, A. (2012). Audit Fees after IFRS Adoption: Evidence from Malaysia. Eurasian Business Review, 2(1), 31-46.

Yermack, D. (1996). Higher market valuation of companies with a small board of directors. Journal of Financial Economics, 40(2), 185-211. https://doi.org/10.1016/0304-405X(95)00844-5

Yin, F., Gao, S., Li, W., \& Lv, H. (2012). Determinants of audit committee meeting frequency: Evidence from Chinese listed companies. Managerial Auditing Journal, 27(4), 425-444. https://doi.org/10.1108/02686901211218003

\section{Copyrights}

Copyright for this article is retained by the author(s), with first publication rights granted to the journal.

This is an open-access article distributed under the terms and conditions of the Creative Commons Attribution license (http://creativecommons.org/licenses/by/4.0/). 